\title{
IMPLEMENTASI ISLAMIC CORPORATE SOCIAL RESPONSIBILITY (CSR) PADA PT. BUMI LINGGA PERTIWI DI KABUPATEN GRESIK
}

\author{
Indra Kharisma \\ Mahasiswa Program Studi S-1 Ekonomi Islam - Fakultas Ekonomi dan Bisnis - Universitas \\ Airlangga \\ Email: indrakha1709@gmail.com \\ Imron Mawardi \\ Departemen Ekonomi Syariah - Fakultas Ekonomi dan Bisnis - Universitas Airlangga \\ Email: ronmawardi@gmail.com
}

\begin{abstract}
Implementation of Corporate Social Responsibility (CSR) is used later to improve the image of the company and its business existence. Instead of CSR to empower people its delude people with a profit motive. Islamic CSR is that CSR refers to business practices that have an ethical responsibility Islamically, companies incorporate Islamic norms characterized by sincerity commitment in maintaining the social contract in its business practices in halal lawful. This study aimed to reveal the implementation of Islamic CSR PT. Bumi Lingga Pertiwi Gresik.

This study used a qualitative approach with descriptive case study method. The selections of informant are using purposive sampling method. Data collection was conducted by semi-structured interviews and documentation. Analysis of the data using descriptive method.

The results of this study indicate that PT. Bumi Lingga Pertiwi has implemented Islamic CSR based on unity, caliphate, justice and broterhood by creating and running a cooperation agreement in accordance with sharia corridor, provide good service to customers, act fairly and avoid discrimination, provide assistance to the poor in the villages around, helping the development of education and worship, as well as participate protecting the environment by way of planting trees together.
\end{abstract}

\section{Keywords: CSR, Islamic CSR}

\section{PENDAHULUAN}

\section{A. Latar Belakang}

Selama dua puluh tahun terakhir, CSR telah berkembang sebagai kerangka kerja untuk peran bisnis dalam masyarakat (Dusuki \& Abdullah, 2005). Dalam perkembangannya, khususnya di negaranegara berkembang, CSR sangat diharapkan serta dipercaya berperan mengatasi masalah di masyarakat dimana bisnis tersebut beroperasi. Istilah Corporate Social Responsibility (CSR), pertama kali muncul dalam tulisan Sosial Responsibility of the Businessman tahun 1953 sebagai konsep yang digagas Howard Rothmann Bowen ini dianggap 
dapat menjawab keresahan dunia bisnis. CSR diadopsi karena dianggap dapat menjadi penawar kesan buruk perusahaan yang terlanjur terbangun dalam pikiran masyarakat. Jika dilihat, latar belakang adopsi CSR oleh perusahaan sebagaimana diatas justru memberi kesan bahwa praktek CSR seolah hanya menjadi alat untuk membangun citra positif ditengah rusaknya perilaku korporat yang terjadi.

CSR di Barat didasarkan pada pandangan budaya Barat yang cenderung mengesampingkan nilai-nilai ketuhanan dan sangat berbeda dengan CSR Islam (Yusuf dan Bahari, 2011). Selain itu kecenderungan CSR di Barat lebih berorientasi ke dunia, dengan tujuan agar perusahaan dapat diterima oleh masyarakat dan mencari keuntungan bisnis semata. CSR adalah kegiatan yang tidak lepas dari etika bisnis. Etika bisnis merupakan dasar atau jiwa dari pelaksanaan sebuah unit usaha, sementara CSR merupakan manifestasinya. Oleh karena itu, sudah semestinya implementasi CSR diiringi dan dipandu oleh etika bisnis yang baik. Islam memiliki pedoman yang lengkap bagi umatnya dalam menjalani hidup, termasuk pedoman bagaimana sebuah bisnis dijalankan tanpa menjauhkannya dari etika, karena dalam Islam etika dan bisnis merupakan satu kesatuan yang tidak dapat dipisahkan.

Tanggung jawab sosial perusahaan bukanlah hal yang baru dalam Islam. Tanggung jawab sosial sudah mulai eksis dan diterapkan selama 14 abad terakhir. Pembahasan tanggung jawab sosial sering disebutkan dalam Al-Qur'an. Al Qur'an selalu menghubungkan kesuksesan bisnis dan pertumbuhan ekonomi yang sangat dipengaruhi oleh etika pengusaha dalam bisnis mereka. Meskipun ayat-ayat Al-Quran dan Hadits tidak langsung merujuk pada CSR tetapi ada banyak ayat dalam Al Qur'an dan Hadits yang menjelaskan kewajiban individu untuk menanggung kebutuhan orang lain. Oleh karena itu, individu yang bersama-sama untuk menciptakan sebuah perusahaan memiliki kewajiban untuk membantu masyarakat dan memberikan manfaat kepada orang lain.

Islamic CSR adalah CSR yang merujuk kepada praktik bisnis yang memiliki tanggung jawab etis secara Islami, perusahaan memasukkan normanorma agama Islam yang ditandai oleh adanya komitmen ketulusan dalam menjaga kontrak sosial di dalam praktik bisnisnya (Suharto, 2010: 101). Dengan demikian, praktik bisnis dalam kerangka Islamic CSR mencakup serangkaian kegiatan bisnis dalam berbagai bentuknya. Meskipun tidak dibatasi jumlah kepemilikan barang, jasa serta profitnya, namun cara-cara memperolehnya dan pendayagunaan hartanya dibatasi oleh aturan halal dan haram sesuai dengan syariah (Rivai, 2009).

PT. Bumi Lingga Pertiwi (PT. BLP) adalah sebuah perusahaan yang bergerak di bidang developer atau pengembang perumahan. PT. BLP 
sebagai sebuah perusahaan yang terdiri dari individu yang terbentuk dalam sebuah satu kesatuan memiliki tanggung jawab kepada setiap elemen di lingkungan bisnisnya, baik kepada internal maupun eksternal perusahaan. Tanggung jawab disini bermakna tanggung jawab kepada dzat yang tertinggi yaitu Allah Swt. sebagai Sang Pencipta, tanggung jawab diri sendiri dengan manusia lainnya, dengan alam dan semua makhluk lainnya, sementara secara operasionalnya, tanggung jawab menjalankan bisnis sesuai dengan aturan syariah, tanggung jawab untuk saling menghormati, saling hidup berdampingan, pelayanan yang baik, pengembangan organisasi dan karyawan serta perlindungan alam. Hal tersebut terwujud dengan menjaga akad-akad kerjasama, menghindari pendapatan yang tidak halal, mensejahterakan karyawannya dengan tunjangantunjangan, menciptakan suasana kerja yang aman dan nyaman, menjunjung tinggi persaudaraan dalam bekerja dan melestarikan serta melindungi lingkungan dengan cara melakukan tanam pohon serta memastikan aktivitas bisnisnya tidak merusak lingkungan. Selain itu PT. BLP juga tidak lupa membantu dan mendukung kesejahteraan sosial dengan membantu pembangunan sarana pendidikan dan sarana ibadah tanpa ada motif mencari keuntungan serta bersedekah kepada warga dusun miskin.

\section{LANDASAN \\ TEORI \\ PENGEMBANGAN PROPOSISI}

DAN

\section{A. Etika Bisnis}

Istilah etika diartikan sebagai suatu perbuatan standar (standard of conduct) yang memimpin individu dalam membuat keputusan. Etika bersumber dari moralitas yang merupakan sistem nilai tentang bagaimana kita harus hidup secara baik sebagai manusia (Keraf dan Sonny, 1991: 20). Baron (2006: 694) mendefinisikan etika sebagai suatu pendekatan sistematis atas pertimbangan moral berdasarkan penalaran, analisis, sintesis dan perenungan. Secara lebih khusus, makna etika bisnis menunjukkan perilaku etis maupun tidak etis yang dilakukan manajer dan karyawan dari suatu organisasi perusahaan (Griffin dan Ebert, 1999: 82). Etika bisnis disebut juga etika manajemen, yaitu penerapan standar moral ke dalam kegiatan bisnis (Alma \& Juni, 2009: 202).

\section{B. Sejarah Perkembangan Konsep Corporate Social Responsibility}

Konsep awal corporate social responsibility (CSR) secara eksplisit baru dikemukakan oleh Howard R. Bowen (Carroll, 1999) melalui karyanya yang berjudul "Social Responsibilities of the Businessmen". Steiner and John (1994: 105110) memandang rumusan Bowen mengenai tanggung jawab sosial yang dilakukan oleh pelaku bisnis sebagai kelanjutan dari pelaksanaan berbagai kegiatan derma (charity) sebagai wujud kecintaan manusia terhadap sesama manusia (philanthropy) yang banyak dilakukan oleh para pengusaha ternama 
pada akhir abad ke-19 sampai periode tahun 1930-an. Sejak kurun waktu tahun 1930-an sampai 1960-an, terdapat tiga tema cara pandang yang berkaitan untuk menjelaskan CSR yang digunakan oleh para pemimpin bisnis, yaitu trusteeship, balancing of interest and service yang telah memperoleh penerimaan yang semakin besar dari pelaku bisnis.

Periode awal tahun 1970-an mencatat babak penting perkembangan konsep CSR ketika para pimpinan perusahaan terkemuka di Amerika serta para peneliti yang diakui dalam bidangnya membentuk Committee for Economic Development (CED). Salah satu pernyataan CED (1971) yang dituangkan dalam laporan berjudul "Social Responsibilies of Business Corporation" menyebutkan:

"Saat ini, sudah jelas bahwa istilah kontrak sosial antara masyarakat dan pelaku usaha telah mengalami perubahan yang substansial dan penting. Pelaku bisnis dituntut untuk memikul tanggung jawab yang lebih luas kepada masyarakat dibanding waktu-waktu sebelumnya serta mengindahkan beragam nilai-nilai manusia. Perusahaan diminta untuk memberikan kontribusi lebih besar bagi kehidupan bangsa Amerika dan bukan sekedar memasok sejumlah barang dan jasa."

Selanjutnya CED membagi CSR ke dalam tiga lingkaran tanggung jawab, yakni inner circle of responsibilities, intermediate of responsibilities, dan outer circle of responsibilities. Lingkaran tanggung jawab terdalam (inner circle of responsibilities), lingkaran tanggung jawab pertengahan (intermediate of responsibilities), lingkaran tanggung jawab terluar (outer circle of responsibilities).

Di penghujung tahun 1980-an, The World Commission on Enviroment and Development yang lebih dikenal dengan The Brundtland Commission mengeluarkan laporan yang dipublikasikan oleh Oxford University Press berjudul "Our Common Future". Salah satu poin penting dalam laporan tersebut adalah diperkenalkannya konsep pembangunan berkelanjutan (sustainability development), yang didefinisikan oleh The Brundtland Commission sebagai berikut: "Pembangunan berkelanjutan adalah pembangunan yang dapat memenuhi kebutuhan manusia saat ini tanpa mengorbankan kemampuan generasi yang akan datang dalam memenuhi kebutuhan mereka". Pengenalan konsep sustainability development memberi dampak besar kepada perkembangan konsep CSR selanjutnya.

Sebagai adopsi atas konsep sustainable debelopment, saat ini perusahaan secara sukarela menyusun laporan setiap tahun yang dikenal dengan sustainability report atau beberapa perusahaan menggunakan nama corporate citizenship report. Laporan tersebut menguraikan dampak organisasi perusahaan terhadap tiga aspek, yakni dampak operasi perusahaan 
terhadap ekonomi, sosial, dan lingkungan. Salah satu model awal yang digunakan oleh perusahaan dalam menyusun sustainability report mereka adalah dengan mengadopsi metode akuntansi baru yang dinamakan triple bottom line. Menurut Elkington (1997), konsep triple bottom line merupakan perluasan dari konsep akuntansi tradisional yang hanya memuat bottom line tunggal yakni hasilhasil kevangan dari aktivitas ekonomi perusahaan. Secara lebih rinci, Elkington menjelaskan konsep tersebut sebagai berikut: Tiga garis dari triple bottom line mewakili masyarakat, ekonomi dan lingkungan.

\section{Ruang lingkup CSR}

CSR bekaitan dengan cara suatu bisnis bertindak terhadap kelompok dan pribadi lainnya dalam lingkungan sosialnya. Kelompok-kelompok dan individu tersebut disebut sebagai pihak pemercaya dalam organisasi (organizational stakeholders). Pihak pemercaya dalam organisasi yaitu kelompok, orang dan organisasi yang langsung dipengaruhi praktik-praktik suatu organisasi sehingga berkepentingan terhadap organisasi itu. Griffin \& Ebert (2003: 119) dalam Alma \& Juni (2009: 182) menyebutkan tujuh ruang lingkup dalam CSR dimana sebuah perusahaan harus bertanggung jawab kepada pihak-pihak tersebut yaitu, pelanggan, karyawan, investor, pemasok, dan komunitas lokal.

\section{Manfaat CSR}

Menurut Suharto (2010: 52-53) jika dikelompokkan, sedikitnya ada empat manfaat CSR terhadap perusahaan yaitu, pertama, Brand Differentiation dengan cara memberikan citra perusahaan yang khas, baik dan etis. Kedua, Human Resources dapat membantu dalam perekrutan karyawan baru, terutama yang memiliki kualifikasi tinggi, bagi staf lama, CSR juga dapat meningkatkan persepsi, reputasi dan motivasi dalam bekerja. Ketiga, License to Operate dapat mendorong pemerintah dan publik memberi "izin" atau "restu" bisnis. Keempat Risk Management berguna untuk mencegah dan mengurangi skandal korupsi, kecelakaan karyawan, atau kerusakan lingkungan.

\section{E. Implementasi CSR}

Keterlibatan perusahaan dalam tanggung jawab sosial dan moral dapat diimplementasikan dalam kegiatan bisnis perusahaan. Hal tersebut dimaksudkan agar tanggung jawab sosial dan moral itu benar-benar terlaksana. Agar implementasi tersebut dapat dilaksanakan, maka perusahaan harus mengetahu kondisi internal tertentu yang memungkinkan terwujudnya tanggung jawab sosial dan moral tersebut.

\section{Pendekatan CSR}

Menurut Wibisono (2007) terdapat empat model pola tanggung jawab sosial perusahaan yang umum diterapkan di Indonesia yaitu, pendekatan langsung, melalui yayasan atau organisasi sosial perusahaan, bermitra dengan pihak lain, mendukung atau bergabung dalam suatu konsorsium. 
Jika ditinjau dari motivasinya, tanggung jawab sosial perusahaan dapat dibedakan menjadi 4 dimensi, yaitu: corporate giving, corporate philanthropy, corporate community relations, dan community development. CSR sering diartikan sebagai kegiatan donasi perusahaan atau sekedar ketaatan perusahaan pada hukum dan aturan yang berlaku (misalnya taat pada aturan mengenai standar upah minimum, tidak memperkerjakan tenaga kerja di bawah umur, dan lain-lain). Padahal, kegiatan donasi (philanthropy) dan ketaatan perusahaan pada hukum tidak dapat dikatakan sebagai CSR. Kegiatan donasi dan ketaatan perusahaan pada hukum hanya syarat minimum agar perusahaan dapat beroperasi dan diterima oleh masyarakat (Wibisono, 2007).

Dapat dilihat bahwa tujuan kegiatan philanthrophy adalah kegiatan yang bersifat amal (charity). Sebuah kegiatan amal tidak memerlukan komitmen berkelanjutan dari perusahaan. Tanggung jawab perusahaan terhadap sebuah kegiatan philanthropy berakhir bersamaan dengan berakhirnya kegiatan amal yang dilakukan perusahaan tersebut. Lebih dari sekedar philanthropy atau sumbangan perusahaan, CSR adalah suatu komitmen bersama dari seluruh stakeholders perusahaan untuk bersama-sama bertanggung jawab terhadap masalah-masalah sosial. Jadi, CSR bukan merupakan sumbangan dari salah satu atau lebih stakeholder perusahaan (misalnya berusaha penyisihan keuntungan dari pemegang saham untuk kegiatan sosial), tetapi menjadi tanggungan seluruh stakeholders.

\section{Tahapan Perumusan Kegiatan} Tanggung Jawab Sosial Perusahaan

Dalam merumuskan keputusan yang tepat untuk melaksanakan tanggung jawab sosial perusahaan, para manajer dan perencana program melalui beberapa tahapan (Kotler, 2005: 18 - 21):

1. Memilih suatu masalah sosial Tahapan ini merupakan suatu tahap awal yang penting dilakukan untuk memutuskan satu dari beberapa masalah sosial yang ingin didukung. Keputusan awal ini mempunyai pengaruh yang besar pada program dan hasil berikutnya.

2. Memilih inisiatif untuk membuat kegiatan terhadap masalah sosial Ketika masalah sosial telah ditentukan, manajer akan ditantang untuk menentukan inisiatif apa yang akan dilakukan untuk memberikan perhatian pada masalah sosial tersebut.

3. Mengembangkan dan melaksanakan rencana program Pada poin ini keputusan yang diambil meliputi beberapa hal penting mengenai apakah pelaksanaan kegiatan harus bermitra dengan pihak lain atau tidak, dan siapakah mitra yang akan dipilih.

4. Evaluasi hasil 
Pengukuran yang dilakukan secara berkelanjutan di dalam kegiatan marketing dan investasi financial bagi perusahaan memiliki catatan panjang, dengan pengalaman yang cukup lama didalam membangun sistem acuan yang canggih dan data base yang menyediakan anlisis pengembalian investasi dan membandingkan aktifitas sekarang dengan target dan standar.

\section{F. Pandangan Islam terhadap CSR}

Konsep CSR yang dikembangkan di Barat tidak sama dengan konsep CSR dalam Islam. Yusuf dan Bahari (2011), menyebutkan dua perbedaannya, pertama perkembangan nilai-nilai dan budaya. Kedua adalah dasar atau prinsipprinsip nilai dan budaya. CSR dalam Islam dibangun atas dasar tasawur (pandangan dunia) dan epistemologi Islam yang berbeda dari CSR yang dikembangkan di Barat, Yusuf dan Bahari (2011).

Pada intinya, pengertian tanggung jawab sosial perusahaan secara Islam adalah sama dengan tanggung jawab sosial dari setiap individu muslim, yaitu menjalankan yang benar dan melarang atau menentang yang salah (Farook, 2007: 35). Pengertian benar (al-haq) dan salah (al-bathil) dapat diartikan sebagai dua hal yang tumpang tindih. Secara hukumnya, benar (haq) mengacu pada semua yang diperbolehkan atau dianjurkan (halal), sedangkan salah (bathil) mengacu pada semua yang tidak diperbolehkan atau tidak dianjurkan (haram). Dari perspektif hukum Islam, "benar" mengacu pada apa yang seharusnya sedangkan "salah" mengacu pada apa yang tidak adil (Farook, 2007: 35).

Tanggung jawab sosial perusahaan bukanlah hal yang baru dalam Islam. Tanggung jawab sosial sudah mulai eksis dan diterapkan selama 14 abad terakhir. Pembahasan tanggung jawab sosial sering disebutkan dalam Al-Qur'an. Al Qur'an selalu menghubungkan kesuksesan bisnis dan pertumbuhan ekonomi yang sangat dipengaruhi oleh etika pengusaha dalam bisnis mereka.

Islam memberikan perhatian terhadap bisnis melalui aspek moral untuk mencapai keuntungan maksimal. Hal ini menunjukkan bahwa Islam berkaitan dengan perekonomian dan moralitas, yang keduanya tidak dapat dipisahkan. Aspek ini juga ditegaskan oleh Nabi Muhammad Saw. Beliau mengatakan dalam hadist yang diriwayatkan oleh Malik bin Anas: " Seorang pekerja/karyawan berhak untuk setidaknya mendapatkan makanan yang baik dan pakaian dengan ukuran yang layak dan tidak dibebani dengan kemampuan untuk bekerja di luar batas". (Malik, 795, 2: 980).

Islam juga mempertimbangkan kelestarian lingkungan sebagai salah satu tanggung jawab sosial. Semua upaya bisnis harus memastikan kelestarian lingkungan (QS Al-Baqarah [2] ayat 204). Di dalam ayat tersebut dijelaskan 
bagaimana Islam memandang kelestarian lingkungan. Semua upaya bisnis atau non bisnis harus memastikan kelestarian lingkungan. Hubungan antara manusia dan lingkungan sangat dekat dan tidak bisa dipisahkan. Islam telah jelas melarang sesuatu yang berbahaya bagi individu atau lingkungan berbahaya.

Sementara di bidang kesejahteraan sosial, Islam mendorong untuk beramal kepada mereka yang membutuhkan dan keterbatasan kemampuan dalam bekerja melalui sadaqah dan pinjaman kesejahteraan (Qard hasan) (QS AtTaghaabun [64] ayat 16). Ayat ini menjelaskan tanggung jawab muslim untuk membantu orang lain melalui kontribusi amal dan sumbangan, dan kekikiran adalah kekejian di dalam Islam (Yusuf dan Bahari, 2011).

Menurut Yusuf dan Bahari (2011), selain mempengaruhi kesejahteraan sosial, tindakan pinjaman kebajikan juga dapat membawa manfaat ganda bagi individu dan perusahaan. Pertama, pinjaman kebajikan dapat menciptakan citra positif bagi individu dan perusahaan serta dan yang kedua, mendapatkan formasi jaringan bisnis baru yang dapat mengakibatkan peningkatan keuntungan.

Nabi Muhammad Saw. bersabda dalam sebuah hadits yang diriwayatkan oleh Salman bin Amir, "Sedekah bagi kaum miskin adalah amal. Dan amal untuk keluarga memiliki dua keuntungan, yaitu bermanfaat bagi Allah dan memperkuat persaudaraan." (HR. Tirmizi, 1993: Hadis Nomor 653).
Pernyataan diatas menunjukkan bahwa konsep tanggung jawab sosial dan konsep keadilan telah lama ada dalam Islam, selama seperti kehadiran Islam yang dibawa oleh Nabi Muhammad Saw. Nabi Muhammad Saw mewujudkan tanggung jawab sosial dan menciptakan keadilan sesuai dengan tuntunan $\mathrm{Al}$ Qur'an. Demikian juga praktek Nabi Muhammad Saw dalam penerapan tanggung jawab sosial dan keadilan dalam masyarakat menjadi sumber acuan bagi bimbingan kepada generasi berikutnya, yang dikenal sebagai As Sunnah. Kedua Al Qur'an dan As Sunnah telah sangat harmonis dalam menegakkan keadilan yang sejati.

Keberadaan umat muslim di muka bumi memiliki dua tugas, hamba yang taat kepada Allah dan khalifah yang adil (Yusuf dan Bahari, 2011). Hubungan antara kedua tugas utama tesebut haruslah sejalan dan tidak boleh dipisahkan satu sama lain. Sebagai seorang hamba yang menyembah Allah, setiap individu memiliki kewajiban untuk menjadikan semua peristiwa hidupnya sebagai bentuk pengabdian yang sempurna kepada Allah. Dalam hal ini, konsep ibadah perlu dipahami dalam arti yang lebih luas. Ini berarti bahwa selain dari ibadah khusus, setiap individu dituntut untuk melakukan ibadah umum lainnya, semua kegiatan yang membawa kesejahteraan manusia dan alam sesuai dengan kondisi tertentu, dengan niat yang benar dan harus memastikan 
bahwa tindakan-tindakan yang dilakukan sesuai syariah (Yusuf dan Bahari, 2011).

Oleh karena itu, kewajiban CSR Islam adalah tanggung jawab individu yang datang bersama-sama dalam satu perusahaan untuk memberikan dampak positif bagi lingkungan dalam rangka memberdayakan masyarakat yang lemah dan untuk melestarikan lingkungan alam (Yusuf dan Bahari, 2011).

\section{G. Perbedaan CSR dengan Islamic CSR}

Islamic CSR sangatlah berbeda dengan CSR dalam kelembagaan ekonomi sekuler yang di anut oleh perusahaan di Barat. CSR muncul sebagai respon atau jawaban dari terjadinya kesenjangan yang semakin lebar dari waktu ke waktu antara harapan tanggung jawab sosial terhadap lingkungan masyarakat dari bisnis atau corporate dengan kenyataan tanggung jawab sosial perusahaan. Kesenjangan tersebut menimbulkan masalah sosial yang sangan merugikan perusahaan dalam jangka pendek maupun jangka panjang. Perbedaan CSR dengan Islamic CSR akan dijelaskan secara singkat pada tabel 1 berikut ini:

Tabel 1: Perbedaan CSR dengan Islamic CSR

\begin{tabular}{|c|c|c|}
\hline $\begin{array}{c}\text { Keterang } \\
\text { an }\end{array}$ & Islamic CSR & CSR \\
\hline Motif & $\begin{array}{l}\text { Bentuk } \\
\text { pertanggung } \\
\text { jawaban } \\
\text { setiap } \\
\text { individu } \\
\text { kepada Allah } \\
\text { SWT Untuk } \\
\text { mencapai }\end{array}$ & $\begin{array}{l}\text { Menghindari } \\
\text { kerugian } \\
\text { bisnis }\end{array}$ \\
\hline
\end{tabular}

\begin{tabular}{|c|c|c|}
\hline & $\begin{array}{l}\text { misi dan } \\
\text { tujuan utama } \\
\text { dari bisnis } \\
\text { demi } \\
\text { terciptanya } \\
\text { kemaslahata } \\
\text { n bersama } \\
\text { dan } \\
\text { mencapai } \\
\text { falah }\end{array}$ & \\
\hline $\begin{array}{l}\text { Pelaksana } \\
\text { an }\end{array}$ & $\begin{array}{l}\text { Dilaksanakan } \\
\text { dengan ikhlas } \\
\text { meskipun } \\
\text { tidak terjadi } \\
\text { permasalaha } \\
n \text { sosial di } \\
\text { masyarakat } \\
\text { dan } \\
\text { dilaksanakan } \\
\text { sebagai } \\
\text { bentuk } \\
\text { penghamba } \\
\text { an kepada } \\
\text { Allah SWT } \\
\text { agar dapat } \\
\text { mencapai } \\
\text { idrak shilah } \\
\text { billah } \\
\text { (kedekatan } \\
\text { hubungan } \\
\text { dengan Allah } \\
\text { swT karena } \\
\text { mendapat } \\
\text { ridho-Nya) } \\
\text { yang } \\
\text { mengacu } \\
\text { kepada } \\
\text { aturan halal- } \\
\text { haram. }\end{array}$ & $\begin{array}{l}\text { Dilaksanaka } \\
\mathrm{n} \quad \text { ketika } \\
\text { terjadi } \\
\text { permasalah } \\
\text { an sosial di } \\
\text { masyarakat, } \\
\text { dengan } \\
\text { harapan } \\
\text { masyarakat } \\
\text { akan } \\
\text { bersimpati } \\
\text { terhadap } \\
\text { perusahaan } \\
\text { dan tidak } \\
\text { menggangg } \\
\text { U aktivitas } \\
\text { perusahaan. } \\
\text { CSR dilaksanaka } \\
\text { n dengan } \\
\text { terpaksa } \\
\text { dan tidak } \\
\text { dengan } \\
\text { sepenuh } \\
\text { hati, karena } \\
\text { perusahaan } \\
\text { harus } \\
\text { mengikuti } \\
\text { peraturan } \\
\text { yang } \\
\text { ditetapkan } \\
\text { oleh } \\
\text { pemerintah. }\end{array}$ \\
\hline Tujuan & $\begin{array}{l}\text { Mencapai } \\
\text { falah di dunia } \\
\text { maupun } \\
\text { akhirat }\end{array}$ & $\begin{array}{l}\text { Mendapat } \\
\text { simpati dari } \\
\text { masyarakat } \\
\text { agar } \\
\text { perusahaan } \\
\text { terus } \\
\text { berkemban } \\
9 \text { ketika } \\
\text { terjadi } \\
\text { permasalah } \\
\text { an sosial. }\end{array}$ \\
\hline $\begin{array}{l}\text { Implemen } \\
\text { tasi dalam }\end{array}$ & $\begin{array}{l}\text { Terdapat } \\
\text { akad dengan }\end{array}$ & $\begin{array}{l}\text { Tidak } \\
\text { terdapat }\end{array}$ \\
\hline
\end{tabular}




\begin{tabular}{|c|c|c|}
\hline $\begin{array}{l}\text { akad } \\
\text { atau } \\
\text { transaksi }\end{array}$ & $\begin{array}{l}\text { niat kebaikan } \\
\text { tanpa } \\
\text { mengharap } \\
\text { keuntungan } \\
\text { secara } \\
\text { ekonomi di } \\
\text { dunia tapi } \\
\text { lebih } \\
\text { mengedepa } \\
\text { nkan } \\
\text { keuntungan } \\
\text { dan benefit } \\
\text { sosial demi } \\
\text { menjaga } \\
\text { keberlangsun } \\
\text { gan generasi } \\
\text { sekarang dan } \\
\text { yang akan } \\
\text { datang, baik } \\
\text { di dunia } \\
\text { maupun di } \\
\text { akhirat. }\end{array}$ & $\begin{array}{l}\text { akad } \\
\text { dengan niat } \\
\text { kebaikan } \\
\text { tanpa } \\
\text { mengharap } \\
\text { kan } \\
\text { keuntungan } \\
\text { secara } \\
\text { ekonomi di } \\
\text { dunia. }\end{array}$ \\
\hline $\begin{array}{l}\text { Sejarah } \\
\text { kemuncul } \\
\text { an }\end{array}$ & $\begin{array}{l}1500 \text { tahun } \\
\text { yang lampau }\end{array}$ & $\begin{array}{l}\text { Akhir abad } \\
\text { ke-19 }\end{array}$ \\
\hline Definisi & $\begin{array}{l}\text { Menjalankan } \\
\text { yang benar } \\
\text { dan } \\
\text { melarang } \\
\text { atau } \\
\text { menentang } \\
\text { yang salah } \\
\text { (Farook, 2007: } \\
35 \text { ) }\end{array}$ & $\begin{array}{l}\text { Komitmen } \\
\text { perusahaan } \\
\text { untuk } \\
\text { mengelimin } \\
\text { asi atau } \\
\text { meminimalk } \\
\text { an setiap } \\
\text { efek } \\
\text { berbahaya } \\
\text { (harmful } \\
\text { effects) } \\
\text { dalam } \\
\text { masyarakat } \\
\text { dan } \\
\text { memaksimal } \\
\text { kan } \\
\text { keuntungan } \\
\text { jangka } \\
\text { panjang } \\
\text { (Mohr et.al. } \\
\text { 2001, dalam } \\
\text { Dean, 2004). }\end{array}$ \\
\hline
\end{tabular}

Sumber: Anindya (2011), dimodifikasi oleh peneliti

Dengan demikian, CSR hanya reaksi sosial atau kepedulian perusahaan terhadap dampak negatif dari bisnis ekonomi sekuler yang dilakukan secara serakah dan ekspolitatif. Sedangkan Islamic CSR adalah bentuk tanggung jawab setiap individu yang tergabung dalam sebuah perusahaan terhadap bisnis yang dijalankannya terkait dengan aturan halal dan haram. Dengan kata lain, Islamic CSR adalah CSR yang merujuk kepada praktik bisnis yang memiliki tanggung jawab etis secara Islami, perusahaan memasukkan norma-norma agama Islam yang ditandai oleh adanya komitmen ketulusan dalam menjaga kontrak sosial di dalam praktik bisnisnya (Suharto, 2010: 101).

\section{H. Prinsip Islamic CSR}

Prinsip didefinisikan sebagai dasar, awal, aturan dasar. Menurut Juhaya (1995: 69), prinsip adalah awal yang merupakan titik keberangkatan (almabda). Dalam terminologi, prinsip adalah kebenaran universal yang secara alami ada dalam hukum Islam dan titik awal pembangunannya. Ini adalah bentuk hukum dasar dan menghasilkan semua cabang (Juhaya, 1995). Hal ini dapat disimpulkan bahwa prinsip adalah dasar atau fundamental yang digunakan untuk melandasi praktek kerja.

Pelaksanaan Islamic CSR dapat dikategorikan ke dalam tiga dimensi tanggung jawab hubungan. Pertama, adalah hubungan tanggung jawab kepada Allah. Kedua, hubungan tanggung jawab kepada manusia. Dan yang terakhir adalah hubungan tanggung jawab terhadap lingkungan (Yusuf dan Bahari, 2011). Pelaksanaan Islamic CSR adalah perwujudan dari tiga hubungan 
yang kuat dan saling terkait antara satu sama lain, hubungan dengan Allah, hubungan dengan manusia dan hubungan dengan alam. Untuk mengoptimalkan ketiga hubungan dalam pelaksanaan Islamic CSR, haruslah dipandu dengan prinsip-prinsip keesaan Allah, khalifah, keadilan, solidaritas atau persaudaraan. Keempat prinsip ini ditujukan untuk mewujudkan prinsip kelima yaitu penciptaan maslahah (manfaat publik) bagi manusia dan alam. Menciptakan maslahah pada perusahaan adalah tujuan utama dalam melaksanakan semua aktivitas binis termasuk pelaksanaan CSR Islam. Oleh karena itu, semua pelaksanaan CSR dalam perusahaan harus dipandu oleh aturan halal yang digariskan oleh Islam dan meninggalkan larangan apapun yang dicegah dalam Islam. Semua prinsip ini dipraktekkan dengan satu tujuan yaitu pengabdian yang sempurna kepada Allah SWT. Semua prinsip ini dipraktekkan dengan satu tujuan yaitu pengabdian yang sempurna kepada Allah SWT. Prinsipprinsip diatas akan dijelaskan secara singkat di bawah ini:

1. Keesaan (Tauhid)

Manusia menurut fitrahnya adalah beragama tauhid. Manusia diciptakan Allah mempunyai naluri beragama, yaitu agama tauhid yang dengan firman Allah dalam QS Ar-Ruum [30] ayat 30.

Percaya hanya kepada satu tuhan, yaitu Allah Swt, adalah tujuan dari syariah (Mohammed, 2007). Dalam Islam, kepercayaan atau iman adalah penting untuk kesejahteraan manusia (falah). Iman kepada Allah memberikan pondasi yang tepat bagi hubungan dengan orang lain, yang memungkinkan manusia bertindak dengan cara menghormati dan peduli. Iman kepada Allah juga memberikan filter moral, yang diperlukan dalam alokasi dan distribusi sumber daya berdasarkan persaudaraan dan keadilan sosial-ekonomi. Selanjutnya, iman dalam Islam adalah motivasi untuk pemenuhan kebutuhan dan distribusi kekayaan yang adil (Chapra, 1992).

2. Kekhalifahan

Chapra (1992) mengatakan bahwa prinsip kekhalifahan diturunkan langsung dari prinsip keesaan (tauhid) yang menjelaskan tujuan dan perilaku manusia untuk mengatur tanggung jawab sosial dan keadilan sebagai bagian dari kepercayaan (iman). Selain menjadi hamba yang taat kepada Allah SWT, manusia juga dituntut untuk melakukan ibadah umum lainnya, semua kegiatan yang membawa kesejahteraan dan mengembangkan potensi manusia dan alam sesuai dengan kondisi tertentu, dengan niat yang benar dan harus memastikan bahwa tindakan-tindakan diizinkan oleh aturan syariah.

Al Mawdudi menafsirkan arti kata "khalifah" sebagai "wakil Allah di bumi" (Al Mawdudi, 1967: 16-23). Sebagai khalifah, manusia diberi kepercayaan untuk mengelola lingkungan ini melibatkan hubungan manusia dengan sesama manusia dan hubungan manusia dengan ciptaan Allah, termasuk hewan, 
tumbuhan dan lingkungan. Diantara semua makhluk ciptaan Allah manusia lah yang paling tinggi derajatnya, oleh karena itu manusia dipilih Allah untuk mejadi pemimpin di muka bumi, hal ini sesuai dengan firman Allah dalam QS AlAn'am [6] ayat 165.

3. Keadilan

Salim (1994) menyatakan bahwa al-Adl bermakna al-inshaf wa al-sawiyyat artinya: berada di pertengahan dan mempersamakan. Secara etimologis aladl bermakna al-istiwa (keadaan lurus) juga bermakna: jujur, adil, seimbang, sama, sesuai, sederhana, dan moderat (Asse, 2010)

Allah telah menciptakan segala sesuatu dengan sempurna dan seimbang sebagaimana firman-Nya dalam QS AlMulk [67] ayat 3 dan 4. Semua ini mungkin bagi Allah karena Allah Maha Kuasa dan dengan sempurna dapat melaksanakan kehendak dan tujuan-Nya, yaitu cinta, kasih dan kebaikan kepada makhluk-Nya. Sebagai khalifah, manusia seharusnya menerapkan sifat-sifat ini dan memenuhi kewajibannya melalui tanggung jawab sosial dan keadilan dalam rangka menjaga keseimbangan dalam masyarakat, Mohammed (2007). Perintah Allah kepada manusia untuk berlaku adil tertuang dalam QS An-Nisaa' [4] ayat 58 dimana Allah SWT memerintahkan manusia berlaku adil apabila menetapkan hukum di antara manusia, apabila seseorang menetapkan hukum di antara mereka dengan tidak adil, maka kehidupan masyarakat menjadi pincang, dan akan terjadi diskriminasi.

4. Persaudaraan

Persaudaraan dalam Islam biasa disebut "ukhuwah" yang berarti "memperhatikan", perhatian tersebut muncul karena adanya persamaan di antara pihak-pihak yang bersaudara, sehingga makna tersebut kemudian berkembang, dan pada akhirnya ukhuwah diartikan sebagai "setiap persamaan dan keserasian dengan pihak lain, baik persamaan keturunan, dari segi ibu, bapak, atau keduanya, maupun dari segi persusuan (Shihab, 1996: 477).

Islam menekankan pentingnya membangun hubungan persaudaraan antara sesama muslim. Persaudaraan yang dimaksud bukanlah menurut ikatan geneologi tapi menurut ikatan iman dan agama. Banyak nash, baik dalam AlQuran maupun al-Hadits, yang menegaskan bahwa sesama muslim itu bersaudara sebagaimana firman Allah SWT dalam surat Al-Hujuraat [49] ayat 10.

\section{Kriteria dan instrumen Islamic CSR}

Untuk

mengoptimalkan

implementasi Islamic CSR berdasarkan keempat prinsip diatas, Yusuf dan Bahari (2011) menyebutkan enam kriteria dan 32 instrumen guna mengukur tanggung jawab sosial Islam dalam perusahaan. Enam kriteria dan 32 instrumen dalam Islamic CSR tersebut tersaji pada tabel 2 berikut: 
Tabel 2:

Tabel Instrumen dan Kriteria dalam Implementasi Islamic CSR

\begin{tabular}{|c|c|c|}
\hline Kriteria & Item & Prinsip CSR Islam \\
\hline \multirow{4}{*}{$\begin{array}{l}\text { 1. Syariah } \\
\text { Complian } \\
\text { ce } \\
\text { QS 4: } 59 \text {, } \\
\text { QS 23: } 5\end{array}$} & $\begin{array}{l}\text { 1. Akad yang sesuai } \\
\text { dengan koridor syariah } \\
\text { (DSN) }\end{array}$ & Keesaan \\
\hline & $\begin{array}{l}2 . \\
\text { perusahaan yang halal }\end{array}$ & $\begin{array}{l}\text { Keesaan, kekalifahan, } \\
\text { keadilan }\end{array}$ \\
\hline & $\begin{array}{l}\text { 3. Investasi dalam sektor } \\
\text { halal }\end{array}$ & Keesaan, kekalifahan \\
\hline & $\begin{array}{l}\text { 4. Menghindari laba non- } \\
\text { halal }\end{array}$ & $\begin{array}{l}\text { Keesaan, kekalifahan, } \\
\text { keadilan }\end{array}$ \\
\hline \multirow{4}{*}{$\begin{array}{l}2 . \\
\text { Kesetaraa } \\
\text { n } \\
\text { QS 3: } 103 \\
\text { QS 49: } 13 .\end{array}$} & $\begin{array}{ll}\text { 1. Adanya } & \text { nilai-nilai } \\
\text { persaudaraan } & \\
\end{array}$ & Persaudaraan, keadilan \\
\hline & 2. Pelayanan yang baik & Persaudaraan, keadilan \\
\hline & 3. Menghindari diskriminasi & Keadilan \\
\hline & $\begin{array}{l}\text { 4. Memiliki kesempatan } \\
\text { yang sama }\end{array}$ & $\begin{array}{l}\text { Persaudaraan, keadilan, } \\
\text { penciptaan maslahah }\end{array}$ \\
\hline \multirow{9}{*}{$\begin{array}{l}3 . \\
\text { Tanggung } \\
\text { jawab } \\
\text { dalam } \\
\text { bekerja } \\
\text { QS 17: } 36\end{array}$} & 1. Kepercayaan & Keesaan \\
\hline & $\begin{array}{l}\text { 2. Bekerja sesuai dengan } \\
\text { batasan dan tanggung } \\
\text { jawab }\end{array}$ & Keadilan \\
\hline & $\begin{array}{l}\text { 3. Memenuhi setiap } \\
\text { permintaan kontrak }\end{array}$ & Keadilan \\
\hline & 4. Transparansi & Keesaan \\
\hline & $\begin{array}{l}\text { 5. Optimal dalam } \\
\text { menggunakan waktu dan } \\
\text { kemampuan }\end{array}$ & $\begin{array}{l}\text { Keesaan, penciptaan } \\
\text { maslahah }\end{array}$ \\
\hline & $\begin{array}{l}\text { 6. Mengurangi dampak } \\
\text { negatif dari investasi }\end{array}$ & $\begin{array}{l}\text { Keeasaan, penciptaan } \\
\text { maslahah }\end{array}$ \\
\hline & 7. Integritas dalam bekerja & Keesaan, keadilan \\
\hline & 8. Persaingan yang adil & $\begin{array}{l}\text { Keadilan, penciptaan } \\
\text { maslahah }\end{array}$ \\
\hline & 9. Akuntabilitas & $\begin{array}{lr}\text { Keadilan, penciptaan } \\
\text { maslahah, }\end{array}$ \\
\hline \multirow{5}{*}{$\begin{array}{l}4 \\
\text { Jaminan } \\
\text { kesejahter } \\
\text { aan } \\
\text { QS 16:90 }\end{array}$} & $\begin{array}{l}\text { 1. Tempat kerja yang aman } \\
\text { dan nyaman }\end{array}$ & $\begin{array}{l}\text { Kekalifahan, } \\
\text { persaudaraan }\end{array}$ \\
\hline & $\begin{array}{l}\text { 2. Memperoleh hak yang } \\
\text { sesuai }\end{array}$ & Keadilan, persaudaraan \\
\hline & 3. Gaji yang layak & Keadilan, persaudaraan \\
\hline & $\begin{array}{lll}4 . & \text { Pelatihan } & \text { dan } \\
\text { pendidikan } & \\
\end{array}$ & Kekalifahan \\
\hline & 5. Tunjangan dan Asuransi & $\begin{array}{l}\text { Keadilan, kekalifahan, } \\
\text { persaudaraan }\end{array}$ \\
\hline \multirow{4}{*}{$\begin{array}{l}5 . \\
\text { Jaminan } \\
\text { kelestaria } \\
n \\
\text { lingkunga } \\
n \\
\text { QS 30: 41, } \\
\text { QS 7: } 56 .\end{array}$} & $\begin{array}{ll}\text { 1. Memastikan investasi } \\
\text { yang tidak } & \text { merusak } \\
\text { lingkungan } & \\
\end{array}$ & Keesaan, kekalifahan \\
\hline & $\begin{array}{l}\text { 2. Terlibat aktif dalam } \\
\text { melindungi lingkungan }\end{array}$ & Keesaan, kekalifahan \\
\hline & $\begin{array}{l}\text { 3. Mendidik karyawan } \\
\text { untuk peduli dan merawat } \\
\text { lingkungan }\end{array}$ & Keesaan, kekalifahan \\
\hline & $\begin{array}{l}\text { 4. Penggunaan bahan } \\
\text { daur ulang } \begin{array}{r}\text { untuk } \\
\text { memenuhi kebutuhan } \\
\text { perusahaan }\end{array} \\
\end{array}$ & $\begin{array}{l}\text { Kekalifahan, penciptaan } \\
\text { maslahah }\end{array}$ \\
\hline \multirow{4}{*}{$\begin{array}{l}\text { 6. Amal } \\
\text { untuk } \\
\text { pelestaria } \\
\text { n } \\
\text { kebajikan } \\
\text { QS 57: 7, } \\
\text { QS 16:71, } \\
\text { QS 9:7 }\end{array}$} & $\begin{array}{l}\text { 1. Pemilihan investor untuk } \\
\text { mendukung kegiatan } \\
\text { kesejahteraan sosial }\end{array}$ & $\begin{array}{l}\text { Kekalifahan, penciptaan } \\
\text { maslahah }\end{array}$ \\
\hline & $\begin{array}{l}\text { 2. Mengurangi masalah } \\
\text { sosial }\end{array}$ & $\begin{array}{l}\text { Persaudaraan, } \\
\text { penciptaan maslahah }\end{array}$ \\
\hline & $\begin{array}{l}\text { 3. Mendukung dan } \\
\text { membantu mendanai } \\
\text { kesejahteraan }\end{array}$ & $\begin{array}{l}\text { Persaudaraan, } \\
\text { penciptaan maslahah }\end{array}$ \\
\hline & $\begin{array}{lr}4 . \quad \text { Berperan } & \text { untuk } \\
\text { kesejahteraan bukan untuk } \\
\text { mencari } & \text { keuntungan } \\
\text { semata } & \\
\end{array}$ & $\begin{array}{l}\text { Keesaan, kekhalifahan, } \\
\text { Persaudaraan, } \\
\text { penciptaan maslahah }\end{array}$ \\
\hline
\end{tabular}

Sumber: Yusuf \& Bahari (2011), diolah.

\section{HASIL PENELITIAN DAN PEMBAHASAN}

\section{A. Implementasi Prinsip Keesaan (Tauhid)}

\section{dalam Islamic CSR di PT. Bumi Lingga}

\section{Pertiwi}

Prinsip keesaan (tauhid) dalam implementasi Islamic CSR oleh PT. BLP diterapkan dengan cara setiap perbuatan khususnya kegiatan sosial, dilakukan dalam rangka menjalankan perintah Allah Swt, tanpa mengharap balasan serta tidak ada motif untuk mencari keuntungan. Sementara dalam operasionalnya, menghindari akad kontrak yang mengandung unsur gharar, spekulasi, tidak menetapkan bunga dalam memberikan pinjaman kepada pihak peminjam modal, senantiasa transparan mengenai laporan keuangan hingga kualitas rumah yang dijual kepada konsumen, jujur dan tidak pernah mengumbar janji kepada konsumen. PT. BLP ikut menjaga kelestarian lingkungan dengan cara melakukan tanam pohon bersama dan mendidik karyawannya untuk peduli kepada lingkungan dengan cara membiasakan untuk menanam pohon bersama-sama.

\section{B. Implementasi Prinsip Kekhalifahan} dalam Islamic CSR di PT. Bumi Lingga Pertiwi

Prinsip kekalifahan dalam implementasi Islamic CSR oleh PT. BLP diterapkan dengan cara menciptakan suasana yang aman dan nyaman dengan asas kekeluargaan, mengikutsertakan karyawan dalam pelatihan yang 
diadakan Real Estate Indonesia (REI). Kemudian PT BLP peduli terhadap masa depan umat dengan melakukan tanam pohon serta membantu pembangunan sarana pendidikan dan ibadah agar nantinya dapat digunakan oleh generasi anak CuCu.

\section{Implementasi Prinsip Keadilan dalam} Islamic CSR di PT. Bumi Lingga Pertiwi

Prinsip Keadilan dalam implementasi Islamic CSR oleh PT. BLP diterapkan dengan cara melayani seluruh konsumen dengan baik tanpa membeda-bedakan status, suku, agama, dan ras. Memberikan tunjangan kepada setiap karyawan dengan jumlah yang sama pada setiap jabatan, membiayai kuliah bagi anak karyawan dengan pertimbangan tertentu, memberangkatkan empat orang karyawan setiap tahunnya untuk umroh dengan ketentuan yang telah ditetapkan, memberikan porsi kerja kepada karyawan yang sesuai dengan bagian, kemampuan dan tanggung jawab masing-masing. Penetapan promosi jabatan untuk karyawan berdasarkan pengalaman, keahlian dan kemauan untuk belajar.

\section{Implementasi Prinsip Persaudaraan} dalam Islamic CSR di PT. Bumi Lingga Pertiwi

Prinsip persaudaraan dalam implementasi Islamic CSR oleh PT. Bumi Lingga Pertiwi (PT. BLP) diterapkan dengan cara melayani pelanggan dengan baik, sopan dan ramah, senantiasa menerapkan asas kekeluargaan dan tolong menolong dalam bekerja sehingga tercipta suasana kerja yang nyaman dan tidak membosankan. PT. BLP memberikan reward kepada karyawannya berupa umroh gratis bagi yang berprestasi dan memenuhi ketentuan dalam rangka mendidik dan merangsang mereka dalam bentuk kebaikan agar bekerja dengan baik. Memberikan bantuan berupa beras kepada warga dusun miskin di sekitar serta vang di setiap bulan Muharram. Membantu pembangunan sekolah dan masjid dengan cara menyediakan lahan untuk kemudian didirikan bangunan standar layak pakai dan pembayarannya dapat dicicil tanpa menggunakan bunga serta tanpa ada motif mencari keuntungan, murni untuk kepentingan umat.

\section{KESIMPULAN DAN SARAN}

\section{A. Simpulan}

Berdasarkan analisis dan pembahasan yang telah dijelaskan dalam pembahasan, maka dapat diperoleh simpulan sebagai berikut:

1. PT. Bumi Lingga Pertiwi (PT. BLP) belum mengimplementasikan prinsip keesaan (tauhid) secara sempurna karena masih menggunakan bank konvensional berbasis bunga dalam peminjaman dana atau modal.

2. PT. Bumi Lingga Pertiwi (PT. BLP) belum mengimplementasikan prinsip kekhalifahan secara sempurna karena masih menggunakan bank berbasis bunga dalam peminjaman modal, masih terdapat karyawan yang tidak nyaman dalam bekerja, serta belum tersedianya bahanbahan daur ulang di lingkungan 
kantor sebagai bentuk dukungan lain dalam hal pegembangan dan pemanfaatan potensi alam semesta.

3. PT. Bumi Lingga Pertiwi (PT. BLP) belum mengimplementasikan prinsip keadilan secara sempurna karena masih terdapat karyawan yang merasakan ketidaksesuaian porsi kerja.

4. Prinsip persaudaraan dalam implementasi Islamic CSR oleh PT. Bumi Lingga Pertiwi (PT. BLP) telah diterapkan dengan sempurna yaitu dengan cara melayani pelanggan dengan baik, sopan dan ramah, senantiasa menerapkan asas kekelvargaan dan tolong menolong dalam bekerja sehingga tercipta suasana kerja yang nyaman dan tidak membosankan. PT. BLP memberikan reward kepada karyawannya berupa umroh gratis bagi yang berprestasi dan memenuhi ketentuan dalam rangka mendidik dan merangsang mereka dalam bentuk kebaikan agar bekerja dengan baik. Memberikan bantuan berupa beras kepada warga dusun miskin di sekitar serta vang di setiap bulan Muharram serta membantu pembangunan sekolah dan masjid dengan cara menyediakan lahan untuk kemudian didirikan bangunan standar layak pakai dan pembayarannya dapat dicicil tanpa menggunakan bunga serta tanpa ada motif mencari keuntungan, murni untuk kepentingan umat.

\section{B. Saran}

Saran yang dapat diberikan berdasarkan hasil analisis dalam penelitian ini adalah:

1. PT. Bumi Lingga Pertiwi

PT. Bumi Lingga Pertiwi hendaknya tetap mempertahankan penerapan CSR Islam yang telah dilakukan dalam praktik bisnisnya, serta senantiasa meningkatkan dan mengevaluasi pelaksanaan CSR secara Islami dalam setiap aktivitas atau tindakan apapun, khususnya tindakan yang berkaitan dengan usahanya untuk menghindari timbulnya permasalahanpermasalahan yang disebabkan oleh kurang optimalnya implementasi CSR Islam. PT. BLP hendaknya melakukan peminjaman modal usaha kepada bank syariah yang tidak menggunakan bunga serta lebih terjamin kehalalannya. Oleh karena itu, penerapan Islamic CSR yang baik dan benar selain merupakan bentuk tanggung jawab perusahaan terhadap para pemangku kepentingan (stakeholders), juga sebagai salah satu bentuk usaha untuk mewujudkan kelestarian lingkungan sehingga terciptanya kehidupan yang harmonis, selaras dan seimbang.

2. Bagi Penelitian Selanjutnya

Meneliti tentang penerapan Islamic CSR dengan prinsip baru selain prinsip yang 
telah digunakan dalam penelitian ini, yaitu prinsip penciptaan maslahah yang bertujuan untuk mengetahui tingkatan urgensi dari pelaksanaan CSR Islam, selain itu penggunaan alat ukur atau kriteria yang lebih terfokus. Hasil dari penelitian selanjutnya dapat memberikan sumbangsih kepada perusahaan lainnya baik lembaga keuangan Islam maupun perusahaan umum untuk mempraktekkan konsep Islamic CSR.

\section{DAFTAR PUSTAKA}

Al Tirmizi. 1993. Sunan Al Tirmizi, Kuala Lumpur, Victory Agency.

Alma, Buchari., Donni Juni Priansa. 2009. Manajemen Bisnis Syariah. Penerbit Alfabeta. Bandung.

Al-Mawdudi, Abu al-A'la. 1967. Islamic Way of Life. Delhi: Markazi Maktaba Islami.

Anindya, Tiara.V. 2011. Pengaruh Fungsi Sosial Terhadap Citra Perusahaan dan Istiqomah pada Nasabah Bank Syariah Mandiri di Surabaya. Skripsi Tidak Diterbitkan. Surabaya Fakultas Ekonomi dan Bisnis Universitas Airlangga.

Asse, Ambo. 2010. Konsep Adil dalam AlQur'an. Al- Risalah. Vol. 10 No. 2.

Baron dan P. David. 2006. Business and It's Enviroment. Edisi ke-5. Upper Saddle River, New Jersey: Pearson Education Inc.

Carroll dan B. Archie. 1999. Corporate Social Responsibility. Business and
Society. Chicago. Vol.38, September.

Chapra, M.U. 1992. Islam and the Economic Challenge. Herndon, $\checkmark A$.

Dusuki, Asyraf Wajdi \& Nurdianawati, Irwani Abdullah. 2005. Maqashid al-shari'ah, Maslahah, dan Corporate Social Responsibility. The American Journal of Islamic Social Sciences. Vol. 24 No.1.

Elkington, J. 1997. Cannibals with Forks: The Triple Bottom Line of $2^{1 \text { st }}$ Century Business. Capstone. Oxford

Farook, Sayd. 2007. On corporate social responsibility of Islamic financial institutions. Islamic Economic Studies. Vol. 15 No.1: 32-46

Griffin, W. Ricky, Ebert dan J. Ronald. 1996. Bussiness. Edisi ke-5. Mc Graw Hill.

Juhaya, S. Praja. 1995. Filsafat Hukum Islam, LPPM Unisba, Bandung, Indonesia

Kotler, Philip and Lee, Nancy. 2005. Corporate social responsibility: doing the most good for your company and your cause. New Jersey: John Wiley and Sons, Inc

Malik. 1951. Al-Muwatta. Kairo, Malik, v.2, h.980: 40

Mohammed, J. A. 2007. Corporate social responsibility in Islam. Doctoral dissertation, AUT University

Salim, Abd. Muin. 1994. Fiqh Siyasah Konsepsi Kekuasaan Politik dalam Al-Quran. Jakarta: LSKI

Shihab, M. Quraish. 1996. Wawasan AlQur"an Tafsir Maudhu"i atas 
Pelbagai Persoalan Umat.

Bandung: Mizan.

Steiner A. George dan F. John. 1994.

Business, Goverment and Society: AA managerial Perspective. Edisi ke-7. McGraw-Hill International Edition.

Suharto, Edi. 2010. CSR\&COMDEV Investasi kreatif perusahaan di era globalisasi. Bandung: Alfabeta

Wibisono, Yusuf. 2007. Membedah konsep dan aplikasi CSR. Gresik: Fascho Publishing

Yusuf, Muhammad Y., \& Zakaria Bahari. 2011. Islamic Corporate Social Responsibility in Islamic Banking: Towards Poverty Alleviation. International Conference on Islamic Economics and Finance. vol. 10. 


\title{
FAKTOR KEPUASAN KERJA TERHADAP KINERJA ISLAM PADA KARYAWAN MUSLIM TENAGA KEPENDIDIKAN DI FAKULTAS EKONOMI DAN BISNIS UNIVERSITAS AIRLANGGA
}

\author{
Angga Bayu Pradhana \\ Mahasiswa Program Studi S-1 Ekonomi Islam - Fakultas Ekonomi dan Bisnis - Universitas \\ Airlangga \\ Ari Prasetyo \\ Departemen Ekonomi Syariah - Fakultas Ekonomi dan Bisnis - Universitas Airlangga \\ Email: ari_feunair@yahoo.co.id
}

\begin{abstract}
The purpose of this study was to determine the effect of job satisfaction factors on Islamic performance against Muslims employee of Workforce Education in Faculty of Economics and Business Airlangga University.

This study used a questionnaire in the primary data collection and quantitative approach to the multiple regression analysis method. Criteria in this study population is Muslim employee education personnel status as a civil servant at the Faculty of Economics and Business Airlangga University totaling 87 people, consisting of 85 Muslim employees and 2 non-Muslim employees. While the sample in this study amounted to 85 Muslim employees. Sampling using sampling saturated technique, because the population in this study is less than 100 people.

The results showed that the factors work itself, salary or wages, and co-workers has a positive effect (unidirectional) and partially significant to the Islamic performance. While factors promotional opportunities and working conditions negatively (opposite) and partially not significant to the Islamic performance, and supervision factors and partially significant positive effect on the Islamic performance. While simultaneously, 6 exogenous variables have a significant effect on the Islamic performance Muslim employees of educational staff in the Faculty of Economics and Business Airlangga University.
\end{abstract}

Key words: Job Satisfaction, Islamic Performance, Employee

\section{PENDAHULUAN}

\section{A. Latar Belakang}

Sumber daya manusia yang ada dalam Islam adalah sumber daya yang dimanfaatkan untuk ibadah kepada Allah, bukan untuk yang lainnya. Dengan adanya rasa menerima amanah dari Allah maka kemampuan yang dimiliki akan ditingkatkan dan dilakukan dalam rangka menjalankan amanah yang diemban. Sifat yang akan tercermin dari sumber daya manusia Islami yang baik ialah siddiq, amanah, fatonah dan tabligh. Keempat sifat

ini adalah tolak ukur yang riil untuk mengukur keunggulan sumber daya manusia Islami.

Islam menganjurkan untuk melakukan tugas-tugas dan pekerjaan tanpa ada penyelewengan dan kelalaian, dan bekerja secara efisien dan penuh kompentensi. Ketekunan dan ketabahan dalam bekerja dianggap sebagai sesuatu yang mempunyai nilai terhormat. Suatu pekerjaan kecil yang dilakukan secara konstan dan profesional lebih baik dari sebuah pekerjaan besar yang dilakukan dengan cara musiman dan tidak professional.

Karyawan unggulan tentunya memiliki etos kerja yang tinggi dalam melakukan setiap pekerjaannya. Mereka memandang pekerjaannya sebagai pekerjaan yang menarik. Mereka berusaha untuk memahami pekerjaan yang dilakukannya serta bertanggung jawab atas pekerjaannya. Tinggi rendahnya etos kerja tiap individu bergantung pada bagaimana individu memandang pekerjaannya tersebut. Ełos 
kerja yang tinggi diperoleh dari karyawan yang merasa puas dengan pekerjaannya.

Namun pada kenyataannya,tidak semua karyawan dapat memperoleh kepuasan kerja seperti yang diharapkan. Adanya birokrasi serta aturan internal pada masing-masing lembaga yang menyebabkan munculnya ketidakpuasan pada karyawan dalam pekerjaan yang telah didapat. Ketidakpuasan ini akan disalurkan dengan tingkat absensi yang tinggi, keterlambatan karyawan, kesengajaan dalam memperlambat pekerjaan serta tidak merasa bertanggung jawab terhadap kemajuan lembaga. Sebagaimana yang dikemukakan oleh Luthans (2001:144) bahwa, "organisasi yang tidak mampu memberikan kepuasan kerja pada karyawannya, akan menghadapi resiko penurunan produktifitas, meningkatnya turn over dan tingginya tingkat absensi karyawan,serta memungkinkan meningkatnya kecelakaan kerja, menurunnya kesehatan fisik dan mental karyawan".

Pentingnya pengorganisasian kinerja karyawan perlu dilakukan, sebagaimana ditegaskan oleh Gibson (1996: 190), bahwa karyawan (pimpinan atau bawahan) mempunyai kekuatankekuatan yang senantiasa melahirkan konsekuensi-konsekuensi behavioral (tingkah laku).

Berdasarkan uraian diatas, maka masalah penelitian ini dapat dirumuskan sebagai berikut: (1) Apakah faktor-faktor kepuasan kerja yang terdiri dari pekerjaan itu sendiri, gaji atau upah, peluang promosi, kondisi kerja, kelompok kerja dan pengawasan berpengaruh terhadap kinerja Islam karyawan muslim tenaga kependidikan di Fakultas Ekonomi dan Bisnis Universitas Airlangga? (2) Diantara faktor-faktor kepuasan kerja tersebut manakah yang berpengaruh dominan terhadap kinerja Islam karyawan muslim tenaga kependidikan di Fakultas Ekonomi dan Bisnis Universitas Airlangga?

\section{LANDASAN TEORI PENGEMBANGAN HIPOTESIS}

DAN

\section{A. Kepuasan Kerja}

Kepuasan kerja merupakan sikap emosional yang menyenangkan dan mencintai pekerjaannya. Sikap ini dicerminkan oleh moral kerja, kedisiplinan dan prestasi kerja (Hasibun, 1994:222).

Sutarto (2010:97) memberikan pernyataan bahwa kepuasan adalah suatu perasaan menyenangkan merupakan hasil dari persepsi individu dalam rangka menyelesaikan tugas atau memenuhi kebutuhannya untuk memperoleh nilai-nilai kerja yang penting bagi dirinya. Anoraga (2006: 82) mendefinisikan kepuasan kerja sebagai suatu sikap yang positif yang menyangkut penyesuaian diri yang sehat dari para karyawan terhadap kondisi dan situasi kerja, termasuk di dalamnya masalah upah, kondisi sosial, kondisi fisik dan kondisi psikologis.

Handoko (1991:193) berpendapat bahwa kepuasan kerja merupakan keadaan emosional yang menyenangkan atau tidak menyenangkan dengan mana para pekerja memandang pekerjaan mereka. Lebih jauh dikatakan bahwa kepuasan kerja mencerminkan perasaan sesorang terhadap pekerjaannya, yang dapat terlihat dari sifat positif pekerja terhadap pekerjaannya dan segala sesuatu yang dihadapi pada lingkungan kerja.

Berdasarkan pendapat beberapa ahli diatas mengenai definisi kepuasan kerja, dapat disimpulkan bahwa kepuasan kerja merupakan suatu sikap yang menyangkut penyesuaian diri dari para karyawan terhadap kondisi dan situasi kerja, termasuk didalamnya masalah upah, kondisi sosial, kondisi fisik dan kondisi psikologis.

Menurut Luthans (2005: 120), terdapat 6 faktor penting yang mempengaruhi kepuasan kerja karyawan:

1. The work itself, the extent to which the job provides the individual with 
interesting task, opportunities for learning, and the chance to accept resposibility. Pekerjaan itu sendiri, yaitu sejauh mana karyawan memandang pekerjaannya sebagai pekerjaan yang menarik, memberikan kesempatan untuk belajar, dan peluang untuk menerima tanggung jawab.

2. Pay, the amount of financial renumeration that is received and the degree to which that is viewed aquitable vis-a-vis that of other in organization. Gaji atau upah, yaitu jumlah balas jasa finansial yang diterima karyawan dan tingkat dimana hal ini dipandang sebagai suatu hal yang adil dalam organisasi.

3. Promotion opportunities, the chance for advancement in the hierarchy. Peluang promosi, yaitu kesempatan untuk memperoleh jabatan yang lebih tinggi.

4. Supervision, the abilities of the supervisor to provide technical assistance and behavioral support. Supervisi atau pengawasan, yaitu kemampuan penyelia dalam memberikan bantuan secara teknis dan memberikan dukungan.

5. Co-worker, the degree to which fellow worker are technically proficient socially suportive. Rekan sekerja, yaitu suatu tingkatan dimana rekan sekerja memberikan dukungan.

6. Working condition, if the working condition are good (clean, attractive, surrounding, for instance) the personnel will find it easier to carry out their job. Kondisi kerja, apabila kondisi kerja karyawan baik (bersih, menarik, dan lingkungan kerja yang menyenangkan) akan membuat mereka mudah menyelesaikan pekerjaannya.

\section{B. Kinerja Islam}

Kinerja Islam adalah serangkaian hasil yang diperoleh dari kemampuan, usaha, dan kesempatan selama periode waktu tertentu, dan di dalam mencapai tujuannya tersebut selalu berupaya penuh kesungguhan untuk mewujudkan prestasi yang optimal sebagai bukti pengabdian dirinya kepada Allah SWT.

Menurut Chablullah (2002), bahwa Islam mempunyai penilaian kinerja tersendiri yang meliputi beberapa unsur sebagai berikut :

a. Niatnya bekerja adalah karena Allah. Orang yang mati pada waktu mencari nafkah baik untuk keluarga maupun dirinya sendiri karena Allah, maka akan termasuk mati syahid.

b. Dalam bekerja harus memberlakukan kaidah secara totalitas. Dapat bekerja menjadi petani, nelayan, peternak, pembantu rumah tangga, pegawai Negara, dan lain sebagainya. Di pihak lain yang tidak bekerja sebagai perampok, pencuri, pelacur, penjudi dan jenis pekerjaan lain yang dilarang agama. Hal ini berarti manusia dapat melakukan pekerjaan secara total, artinya mereka bekerja sesuai dengan kapasitas pekerjaan yang telah diberikan. Selain itu manusia dapat melakukan berbagai macam pekerjaan selama tidak dilarang oleh agama.

c. Motivasinya adalah untuk mencari "keberuntungan" di dunia dan akhirat. Keberuntungan di sini artinya setelah manusia bekerja dan berusaha yang menentukan berhasil tidaknya adalah Allah yang Maha Kuasa. Hasil pekerjaan orang kafir hanya dapat dinikmati di dunia saja. Hal ini berarti manusia yang termotivasi cenderung dalam melakukan setiap pekerjaannya secara tepat waktu.

d. Dalam bekerja dituntut penerapan asas efisiensi dan manfaat dengan tetap menjaga kelestarian lingkungan alam. Hal ini berarti manusia dituntut untuk memanfaatkan sumber daya yang tersedia secara optimal tanpa merugikan lingkungan sekitar.

e. Menjaga keseimbangan antara mencari harta dengan beribadah. Hadist Rasulullah memberikan petunjuk sebagai berikut: 


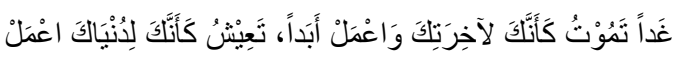
"Carilah harta seolah-olah kamu hidup seribu tahun lagi dan beribadah seolah-olah kalian mati besok pagi."

Hal ini dituntut demikian karena pada dasarnya: lahir, rizki, jodoh dan mati mutlak merupakan takdir Allah.

f. Setelah berhasil dalam pekerjaan hendaknya bersyukur kepada Allah SWT serta membelanjakan rizki yang diperolehnya di jalan Allah SWT pula dengan cara tidak boros dan tidak kikir; mengeluarkan zakat, infak, sedekah, dan naik haji jika sudah memenuhi persyaratan; menyantuni anak yatim, fakir miskin, cacat dan lain sebagainya.

\section{Hubungan antara Kepuasan Kerja dan Kinerja Islam}

Bekerja merupakan sarana untuk mencari rezeki dan kehidupan yang layak sekaligus merupakan suatu tujuan. Manusia mempunyai tujuan hidup yaitu berjuang di jalan kebenaran dan melawan kebatilan. Menurut Al-Qur'an, faktor yang mendekatkan atau menjauhkan manusia dari realisasi tujuan hidup adalah amal yang bermanfaat bagi orang banyak dan tidak merugikan mereka sedikitpun (Mursi, 1997:35).

Islam memerintahkan untuk bekerja dan berusaha guna mencari anugerah Allah SWT sehingga Islam benar-benar menjadi perimbangan hidup. Maka dalam perspektif Islam menetapkan bahwa bekerja merupakan ibadah dan salah satu kewajiban (Mursi, 1997:39).

Untuk mencapai produktivitas kerja yang maksimal, para pekerja perlu memperhatikan adanya hal-hal yang menunjang dalam melakukan pekerjaan mereka agar memperoleh kepuasan kerja sehingga kinerja mereka menjadi lebih baik.

Kepuasan kerja merupakan salah satu dari beberapa faktor yang mempengaruhi tingkat kinerja karyawan. Tanpa adanya kepuasan, karyawan akan bekerja tidak seperti apa yang diharapkan oleh lembaga, maka akibatnya kinerja karyawan menjadi rendah sehingga tujuan lembaga tidak akan tercapai secara maksimal. Karyawan akan merasa puas jika segala sesuatu yang dibutuhkan untuk menunjang pekerjaannya terpenuhi. Karyawan yang merasa puas cenderung melakukan pekerjaannya dengan lebih baik daripada karyawan yang tidak puas.

\section{KERANGKA BERPIKIR}

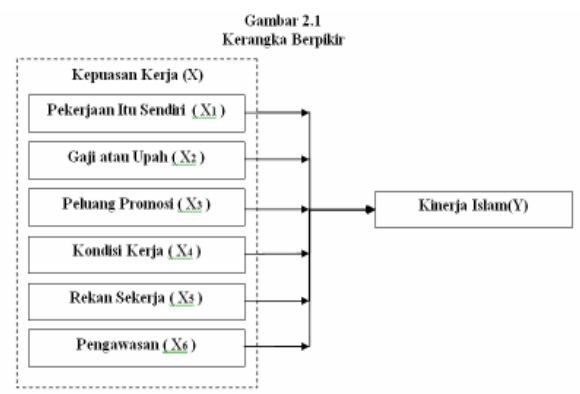

\section{E. HIPOTESIS}

Berdasarkan latar belakang masalah, rumusan masalah, tujuan penelitian, landasan teori, penelitian sebelumnya dan model analisis diatas, maka dapat dikemukakan hipotesis untuk penelitian ini sebagai berikut :

1. Bahwa faktor-faktor kepuasan kerja yang terdiri dari pekerjaan itu sendiri, gaji atau upah, peluang promosi, kondisi kerja, rekan sekerja, dan pengawasan berpengaruh terhadap kinerja Islam karyawan muslim tenaga kependidikan di Fakultas Ekonomi dan Bisnis Universitas Airlangga.

2. Bahwa dari 6 variabel kepuasan kerja yaitu faktor gaji atau upah yang berpengaruh dominan terhadap kinerja Islam karyawan muslim tenaga kependidikan di Fakultas Ekonomi dan Bisnis Universitas Airlangga.

\section{METODOLOGI PENELITIAN}

Tujuan penelitian adalah untuk mengetahui pengaruh faktor kepuasan kerja baik secara parsial maupun simultan terhadap kinerja Islam karyawan muslim Tenaga Kependidikan di Fakultas Ekonomi dan Bisnis Universitas Airlangga.

Responden dalam penelitian ini adalah 85 karyawan muslim Tenaga 
Kependidikan yang berstatus sebagai PNS. Pendekatan penelitian ini menggunakan metode kuantitatif dan model analisis yang digunakan adalah regresi berganda serta teknik pengambilan sampel menggunakan sampling jenuh.

\section{HASIL PENELITIAN DAN PEMBAHASAN Tabel 1.}

Regresi Linier Berganda

\begin{tabular}{|c|c|c|c|}
\hline Model & $\begin{array}{l}\text { Koefisien } \\
\text { Regresi }\end{array}$ & $\begin{array}{c}t \\
\text { hitung }\end{array}$ & Sig. \\
\hline Konstanta & 0,818 & 2,753 & 0,007 \\
\hline $\begin{array}{l}\text { Pekerjaan itu } \\
\text { Sendiri }\left(X_{1}\right)\end{array}$ & 0,209 & 2,160 & 0,034 \\
\hline $\begin{array}{l}\text { Gaji atau } \\
\text { Upah }\left(X_{2}\right)\end{array}$ & 0,178 & 2,141 & 0,035 \\
\hline $\begin{array}{l}\text { Peluang } \\
\text { Promosi }\left(X_{3}\right)\end{array}$ & $-0,021$ & $\begin{array}{c}- \\
0,231 \\
\end{array}$ & 0,818 \\
\hline $\begin{array}{l}\text { Kondisi Kerja } \\
\left(\mathrm{X}_{4}\right)\end{array}$ & $-0,022$ & $\begin{array}{c}- \\
0,253 \\
\end{array}$ & 0,801 \\
\hline $\begin{array}{l}\text { Rekan } \\
\text { Sekerja }\left(X_{5}\right)\end{array}$ & 0,409 & 3,809 & 0,000 \\
\hline $\begin{array}{l}\text { Pengawasan } \\
\left(X_{6}\right)\end{array}$ & 0,036 & 0,349 & 0,728 \\
\hline \multicolumn{4}{|c|}{$\begin{array}{l}R^{2}=0,442 \\
F \text { Hitung }=10,288(\text { Sig. }=0,000)\end{array}$} \\
\hline
\end{tabular}

Berdasarkan tabel 1. diatas dapat diketahui bahwa hasil uji $\dagger$ untuk variabel pekerjaan itu sendiri $\left(X_{1}\right)$ mempunyai nilai thirung sebesar 2,160 dan nilai signifikansinya (Sig.) sebesar 0,034. Hal ini berarti $X_{1}$ mempunyai nilai thitung $>$ tTabel yaitu 2,160> 1,991 dan nilai signifikansi (Sig.) $<0,05$ yaitu $0,034<0,05$. Maka dapat disimpulkan bahwa $\mathrm{H}_{0}$ ditolak dan $\mathrm{H}_{1}$ diterima, yang artinya variabel pekerjaan itu sendiri $\left(X_{1}\right)$ berpengaruh signifikan secara parsial terhadap kinerja Islam (Y) sebagai variabel endogen.

Hasil uji $\dagger$ untuk variabel gaji atau upah $\left(\mathrm{X}_{2}\right)$ mempunyai nilai thirung sebesar 2,141 dan nilai signifikansinya (Sig.) sebesar 0,035 . Hal ini berarti $X_{2}$ mempunyai nilai thitung $>$ tTabel yaitu 2,141 $>1,991$ dan nilai signifikansi (Sig.) $<0,05$ yaitu 0,035 0,05.
Maka dapat disimpulkan bahwa $\mathrm{H}_{0}$ ditolak dan $\mathrm{H}_{1}$ diterima, yang artinya variabel gaji atau upah $\left(X_{2}\right)$ berpengaruh signifikan secara parsial terhadap kinerja Islam (Y) sebagai variabel endogen.

Hasil uji $\dagger$ untuk variabel peluang promosi $\left(X_{3}\right)$ mempunyai nilai thirung sebesar 0,231 dan nilai signifikansinya (Sig.) sebesar 0,818 . Hal ini berarti $X_{3}$ mempunyai nilai thitung $<$ tTabel yaitu $0,231<1,991$ dan nilai signifikansi (Sig.) $>0,05$ yaitu 0,818 > 0,05. Maka dapat disimpulkan bahwa $\mathrm{H}_{0}$ diterima dan $\mathrm{H}_{1}$ ditolak, yang artinya variabel peluang promosi $\left(X_{3}\right)$ tidak berpengaruh signifikan secara parsial terhadap kinerja Islam (Y) sebagai variabel endogen.

Hasil uji † untuk variabel kondisi kerja $\left(X_{4}\right)$ mempunyai nilai thirung sebesar 0,253 dan nilai signifikansinya (Sig.) sebesar 0,801 . Hal ini berarti $X_{4}$ mempunyai nilai thitung $<$ tTabel yaitu $0,253<1,991$ dan nilai signifikansi (Sig.) $>0,05$ yaitu 0,801 >0,05. Maka dapat disimpulkan bahwa $\mathrm{H}_{0}$ diterima dan $\mathrm{H}_{1}$ ditolak, yang artinya variabel kondisi kerja $\left(\mathrm{X}_{4}\right)$ tidak berpengaruh signifikan secara parsial terhadap kinerja Islam (Y) sebagai variabel endogen.

Hasil uji † untuk variabel rekan sekerja (X) mempunyai nilai thirung sebesar 3,809 dan nilai signifikansinya (Sig.) sebesar 0,000 . Hal ini berarti $X_{5}$ mempunyai nilai thitung $>$ tTabel yaitu 3,809 $>1,991$ dan nilai signifikansi (Sig.) $<0,05$ yaitu 0,000 0,05. Maka dapat disimpulkan bahwa $\mathrm{H}_{0}$ ditolak dan $H_{1}$ diterima, yang artinya variabel rekan sekerja $\left(X_{5}\right)$ berpengaruh signifikan secara parsial terhadap kinerja Islam (Y) sebagai variabel endogen.

Hasil uji $t$ untuk variabel pengawasan $\left(X_{6}\right)$ mempunyai nilai thirung sebesar 0,349 dan nilai signifikansinya (Sig.) sebesar 0,728 . Hal ini berarti $X_{6}$ mempunyai nilai thitung $<$ tTabel yaitu $0,349<1,991$ dan nilai signifikansi (Sig.) $>0,05$ yaitu 0,728 > 0,05 . Maka dapat disimpulkan bahwa $\mathrm{H}_{0}$ diterima dan $\mathrm{H}_{1}$ ditolak, yang artinya variabel pengawasan $\left(X_{6}\right)$ tidak 
berpengaruh signifikan secara parsial terhadap kinerja Islam (Y) sebagai variabel endogen.

Berdasarkan tabel 1. diatas dapat diketahui bahwa dari enam variabel eksogen terdiri dari pekerjaaan itu sendiri, gaji atau upah, peluang promosi, kondisi kerja, rekan sekerja dan pengawasan, yang memberikan pengaruh dominan terhadap kinerja Islam yaitu variabel rekan sekerja karena mempunyai nilai koefisien regresi yang paling besar yaitu 0,409.

Berdasarkan tabel 1. diatas dapat diketahui bahwa nilai Fhitung sebesar 10,288 dan nilai signifikansinya (Sig.) sebesar 0,000 . Hal ini berarti bahwa nilai F Fabel $(10,288>2,22)$ dan mempunyai nilai signifikansi (Sig.) $<0,05$ yaitu 0,000. Maka dapat disimpulkan bahwa $\mathrm{H}_{0}$ dan $\mathrm{H}_{1}$ diterima, yang artinya seluruh variabel eksogen yang terdiri dari pekerjaan itu sendiri $\left(X_{1}\right)$, gaji atau upah $\left(X_{2}\right)$, peluang promosi $\left(X_{3}\right)$, kondisi kerja $\left(X_{4}\right)$, rekan sekerja $\left(X_{5}\right)$ dan pengawasan $\left(X_{6}\right)$ secara bersama-sama atau simultan mempunyai pengaruh yang signifikan terhadap kinerja Islam (Y) sebagai variabel endogen.

\section{A. Pembahasan}

\section{Pengaruh Pekerjaan itu Sendiri Terhadap Kinerja Islam}

Hasil uji hipotesis dari penelitian menunjukkan bahwa faktor pekerjaan itu sendiri mempunyai pengaruh yang positif dan signifikan terhadap kinerja Islam karyawan muslim tenaga kependidikan Fakultas Ekonomi dan Bisnis Universitas Airlangga karena mempunyai nilai thitung $>$ tTabel yaitu 2,160>1,991, hal ini berarti tinggi rendahnya kinerja Islam, salah satunya dapat dijelaskan oleh faktor pekerjaan itu sendiri. Dengan demikian hipotesis yang menyatakan bahwa faktor pekerjaan itu sendiri mempunyai pengaruh secara signifikan terhadap kinerja Islam karyawan muslim tenaga kependidikan Fakultas Ekonomi dan Bisnis Universitas Airlangga terbukti.

Berdasarkan empat indikator pada faktor pekerjaan itu sendiri, sebagian besar responden menjawab setuju dengan persentase masing-masing indikator yaitu indikator $X_{1.1}$ sebesar $49,4 \%$, $X_{1.2}$ sebesar $55,3 \%, X_{1.3}$ sebesar $60 \%$ dan $X_{1.4}$ sebesar $71,8 \%$. Dari empat indikator tersebut, yang mempunyai persentase paling besar adalah $X_{1.4}$ sebesar $71,8 \%$. Hal ini berarti bahwa faktor pekerjaan itu sendiri berpengaruh signifikan terhadap kinerja Islam karyawan muslim tenaga kependidikan Fakultas Ekonomi dan Bisnis Universitas Airlangga karena karyawan setuju bahwa variasi atas pekerjaan yang dilakukan oleh karyawan sudah memuaskan.

Dengan demikian secara keseluruhan dari empat indikator faktor pekerjaan itu sendiri dapat disimpulkan bahwa mereka merasa puas dengan perlakuan perusahaan terhadap pekerjaan para karyawan yang meliputi kesesuaian pekerjaan dengan bakat, kemampuan dan latar belakang pendidikan yang dimiliki, kebebasan dalam menyelesaikan pekerjaan, umpan balik atas hasil pekerjaan (reward), variasi pekerjaan yang dilakukan.

\section{B. Pengaruh Gaji atau Upah Terhadap Kinerja Islam}

Hasil uji hipotesis dari penelitian menunjukkan bahwa faktor gaji atau upah mempunyai pengaruh yang positif dan signifikan terhadap kinerja Islam karyawan muslim tenaga kependidikan Fakultas Ekonomi dan Bisnis Universitas Airlangga karena mempunyai nilai thitung $>$ tTabel yaitu 2,141 > 1,991, hal ini berarti tinggi rendahnya kinerja Islam, salah satunya dapat dijelaskan oleh faktor gaji atau upah.

Dengan demikian hipotesis yang menyatakan bahwa faktor gaji atau upah mempunyai pengaruh secara signifikan terhadap kinerja Islam karyawan muslim tenaga kependidikan Fakultas Ekonomi dan Bisnis Universitas Airlangga terbukti. Sedangkan hipotesis yang menyatakan bahwa faktor gaji atau upah berpengaruh dominan terhadap kinerja 
Islam karyawan muslim tenaga kependidikan Fakultas Ekonomi dan Bisnis Universitas Airlangga tidak terbukti. Hal ini berarti bahwa gaji atau upah bukan lagi menjadi faktor utama penentu kepuasan kerja.

Berdasarkan empat indikator pada faktor gaji atau upah, sebagian besar responden menjawab setuju dengan persentase masing-masing indikator yaitu indikator $X_{2.1}$ sebesar $50,6 \%, X_{2.2}$ sebesar $42,4 \%, X_{2.3}$ sebesar $54,1 \%$ dan $X_{2.4}$ sebesar $48,2 \%$. Dari empat indikator tersebut, yang mempunyai persentase paling besar adalah $X_{2.3}$ sebesar $54,1 \%$. Hal ini berarti bahwa faktor gaji atau upah berpengaruh signifikan terhadap kinerja Islam karyawan muslim tenaga kependidikan Fakultas Ekonomi dan Bisnis Universitas Airlangga karena karyawan setuju bahwa gaji yang mereka terima adil dan sesuai dengan keahlian yang dimiliki oleh karyawan.

Dengan demikian secara keseluruhan dapat disimpulkan dari empat indikator faktor gaji atau upah bahwa karyawan merasa puas dengan sistem penggajian yang dilakukan oleh perusahaan karena sudah sesuai dengan pekerjaan yang dilakukan, tingkat keahlian serta masa kerja dan pengalaman yang dimiliki. Namun karyawan merasa tidak puas dengan sistem penggajian yang dilakukan oleh perusahaan berdasarkan kebutuhan hidup, karena mereka merasa bahwa gaji yang diterima belum mampu untuk memenuhi kebutuhan hidup.

\section{Pengaruh Peluang Promosi Terhadap Kinerja Islam}

Hasil uji hipotesis dari penelitian menunjukkan bahwa faktor peluang promosi mempunyai pengaruh yang negatif dan tidak signifikan terhadap kinerja Islam karyawan muslim tenaga kependidikan Fakultas Ekonomi dan Bisnis Universitas Airlangga karena mempunyai nilai thitung $<$ tTabel yaitu 0,231 < 1,991, hal ini berarti tinggi rendahnya kinerja Islam, tidak dipengaruhi oleh faktor peluang promosi. Dengan demikian hipotesis yang menyatakan bahwa peluang promosi mempunyai pengaruh secara signifikan terhadap kinerja Islam karyawan muslim tenaga kependidikan Fakultas Ekonomi dan Bisnis Universitas Airlangga tidak terbukti.

Berdasarkan tiga indikator pada faktor peluang promosi, sebagian besar responden menjawab setuju dengan persentase masing-masing indikator yaitu indikator $X_{3.1}$ sebesar 58,8\%, $X_{3.2}$ sebesar $56,5 \%$, dan $X_{3.3}$ sebesar $40 \%$. Dari tiga indikator tersebut, yang mempunyai persentase paling kecil adalah $X_{3.3}$ sebesar $40 \%$. Hal ini berarti bahwa faktor peluang promosi tidak berpengaruh signifikan terhadap kinerja Islam karyawan muslim tenaga kependidikan Fakultas Ekonomi dan Bisnis Universitas Airlangga karena karyawan merasa bahwa promosi yang dilakukan oleh perusahaan tidak sesuai dengan penilaian berdasarkan obyektifitas.

Dengan demikian secara keseluruhan dapat disimpulkan dari tiga indikator faktor peluang promosi bahwa karyawan merasa puas dengan kebijaksanaan perusahaan dalam hal kenaikan jabatan dan upaya dalam meningkatkan kemampuan karyawan melalui pelatihan atau pendidikan. Akan tetapi karyawan merasa kurang puas dengan promosi yang dilakukan oleh perusahaan karena tidak sesuai dengan obyektifitas penilaian.

\section{Pengaruh Kondisi Kerja Terhadap Kinerja Islam}

Hasil uji hipotesis dari penelitian menunjukkan bahwa faktor kondisi kerja mempunyai pengaruh yang negatif dan tidak signifikan terhadap kinerja Islam karyawan muslim tenaga kependidikan Fakultas Ekonomi dan Bisnis Universitas Airlangga karena mempunyai nilai thitung < tTabel yaitu 0,253<1,991, hal ini berarti tinggi rendahnya kinerja Islam, tidak dipengaruhi oleh faktor kondisi kerja. Dengan demikian 
hipotesis yang menyatakan bahwa kondisi kerja mempunyai pengaruh secara signifikan terhadap kinerja Islam karyawan muslim tenaga kependidikan Fakultas Ekonomi dan Bisnis Universitas Airlangga tidak terbukti.

Berdasarkan tiga indikator pada faktor kondisi kerja, sebagian besar responden menjawab setuju dengan persentase masing-masing indikator yaitu indikator $X_{4.1}$ sebesar $50,6 \%, X_{4.2}$ sebesar $67,1 \%$, dan $X_{4.3}$ sebesar $54,1 \%$. Dari tiga indikator tersebut, yang mempunyai persentase paling kecil adalah $X_{4.1}$ sebesar $50,6 \%$. Hal ini berarti bahwa faktor kondisi kerja tidak berpengaruh signifikan terhadap kinerja Islam karyawan muslim tenaga kependidikan Fakultas Ekonomi dan Bisnis Universitas Airlangga karena karyawan merasa bahwa tata ruang tempat mereka bekerja kurang nyaman dalam melakukan pekerjaan yang dilakukan.

Dengan demikian secara keseluruhan dapat disimpulkan dari tiga indikator faktor kondisi kerja bahwa karyawan merasa puas dengan penerangan yang berada di ruang kerja dan fasilitas yang tersedia dalam menunjang pekerjaan yang mereka lakukan. Namun, karyawan merasa kurang puas dengan tata ruang tempat mereka bekerja karena kurang nyaman dalam melakukan pekerjaaan yang dilakukan.

\section{E. Pengaruh Rekan Sekerja Terhadap Kinerja Islam}

Hasil uji hipotesis dari penelitian menunjukkan bahwa faktor rekan sekerja mempunyai pengaruh yang positif dan signifikan terhadap kinerja Islam karyawan muslim tenaga kependidikan Fakultas Ekonomi dan Bisnis Universitas Airlangga karena mempunyai nilai thitung $>t_{\text {Tabel }}$ yaitu $3,809>1,991$, hal ini berarti tinggi rendahnya kinerja Islam, salah satunya dapat dijelaskan oleh faktor rekan sekerja. Dengan demikian hipotesis yang menyatakan bahwa faktor rekan sekerja mempunyai pengaruh secara signifikan terhadap kinerja Islam karyawan muslim tenaga kependidikan Fakultas Ekonomi dan Bisnis Universitas Airlangga terbukti. Selain itu faktor rekan sekerja merupakan variabel eksogen yang mempunyai pengaruh dominan terhadap kinerja Islam sebagai variabel endogen, karena karyawan merasa bahwa rekan kerja yang kooperatif akan memberikan dorongan atau semangat untuk bekerja lebih giat lagi sehingga akan meningkatkan kinerja mereka. Selain itu, faktor rekan sekerja mempunyai nilai koefisien regresi yang paling besar yaitu 0,409 .

Berdasarkan 5 indikator pada faktor rekan sekerja, sebagian besar responden menjawab setuju dengan persentase masing-masing indikator yaitu indikator $X_{5.1}$ sebesar $54,1 \%, X_{5.2}$ sebesar $62,4 \%, X_{5.3}$ sebesar $72,9 \%, X_{5.4}$ sebesar $80 \%$ dan $X_{5.5}$ sebesar 70,6\%. Dari 5 indikator tersebut, yang mempunyai persentase paling besar adalah $X_{5.4}$ sebesar $80 \%$. Hal ini berarti bahwa faktor rekan sekerja berpengaruh signifikan terhadap kinerja Islam karyawan muslim tenaga kependidikan Fakultas Ekonomi dan Bisnis Universitas Airlangga karena responden setuju bahwa karyawan merasa puas dengan kemampuan rekan kerja dalam menghadapi pekerjaan yang dilakukan, tidak meragukan kemampuan rekan kerja mereka baik dalam melakukan maupun menyelesaikan pekerjaan yang diberikan.

Dengan demikian secara keseluruhan dari 5 indikator faktor rekan sekerja dapat disimpulkan bahwa karyawan merasa puas dengan rekan kerja mereka baik dalam hal sikap dan perilaku,cara bekerjasama dalam menyelesaikan pekerjaan, kemampuan dalam melakukan pekerjaan, adanya rasa kebersamaan serta hubungan harmonis yang timbul dalam lingkungan kerja mereka. 


\section{F. Pengaruh Pegawasan Terhadap Kinerja Islam \\ Hasil uji hipotesis dari penelitian} menunjukkan bahwa faktor pengawasan mempunyai pengaruh yang positif dan tidak signifikan terhadap kinerja Islam karyawan muslim tenaga kependidikan Fakultas Ekonomi dan Bisnis Universitas Airlangga karena mempunyai nilai thitung < tTabel yaitu 0,349 < 1,991, hal ini berarti tinggi rendahnya kinerja Islam, tidak dipengaruhi oleh faktor pengawasan. Dengan demikian hipotesis yang menyatakan bahwa faktor pengawasan mempunyai pengaruh secara signifikan terhadap kinerja Islam karyawan muslim tenaga kependidikan Fakultas Ekonomi dan Bisnis Universitas Airlangga tidak terbukti.

Berdasarkan tiga indikator pada faktor pengawasan, sebagian besar responden menjawab setuju dengan persentase masing-masing indikator yaitu indikator $X_{6.1}$ sebesar 51,8\%, $X_{6.2}$ sebesar $51,8 \%$, dan $X_{6.3}$ sebesar $67,1 \%$. Dari tiga indikator tersebut, yang mempunyai persentase paling kecil adalah $X_{6.1}$ dan $X_{6.2}$ sebesar $51,8 \%$. Hal ini berarti bahwa faktor pengawasan tidak berpengaruh signifikan terhadap kinerja Islam karyawan muslim tenaga kependidikan Fakultas Ekonomi dan Bisnis Universitas Airlangga karena karyawan merasa kurang puas dengan kemampuan, sikap dan perilaku pengawas.

Dengan demikian secara keseluruhan dapat disimpulkan dari tiga indikator faktor pengawasan bahwa karyawan merasa puas dengan adanya partisipasi yang diberikan pengawas dalam pengambilan keputusan yang berkaitan dengan pekerjaan mereka. Akan tetapi karyawan merasa kurang puas dengan kemampuan, sikap dan perilaku pengawas.

\section{SIMPULAN}

Berdasarkan hasil penelitian yang telah dilakukan, maka dapat disusun simpulan sebagai berikut:
Pertama, seluruh variabel eksogen yang terdiri dari pekerjaaan itu sendiri, gaji atau upah, peluang promosi, kondisi kerja, rekan sekerja dan pengawasan secara bersama-sama atau simultan berpengaruh terhadap kinerja Islam sebagai variabel endogen. Artinya peningkatan pengaruh faktor-faktor kepuasan kerja yang terdiri dari pekerjaan itu sendiri, gaji atau upah, peluang promosi, kondisi kerja, rekan sekerja dan pengawasan secara bersama-sama akan meningkatkan kinerja Islam karyawan muslim tenaga kependidikan Fakultas Ekonomi dan Bisnis Universitas Airlangga.

Kedua, faktor-faktor kepuasan kerja yang terdiri dari pekerjaan itu sendiri,gaji atau upah, dan rekan sekerja mempunyai pengaruh positif dan signifikan secara parsial terhadap kinerja Islam sebagai variabel endogen. Artinya peningkatan pengaruh faktor pekerjaan itu sendiri,gaji atau upah, dan rekan sekerja maka akan meningkatkan kinerja Islam karyawan muslim tenaga kependidikan Fakultas Ekonomi dan Bisnis Universitas Airlangga.

Ketiga, faktor-faktor kepuasan kerja yang terdiri dari peluang promosi dan kondisi kerja mempunyai pengaruh negatif dan tidak signifikan secara parsial terhadap kinerja Islam sebagai variabel endogen. Artinya peningkatan pengaruh faktor peluang promosi dan kondisi kerja maka akan menurunkan kinerja Islam karyawan muslim tenaga kependidikan Fakultas Ekonomi dan Bisnis Universitas Airlangga.

Keempat, faktor pengawasan mempunyai pengaruh positif dan tidak signifikan secara parsial terhadap kinerja Islam sebagai variabel endogen. Artinya peningkatan pengaruh faktor pengawasan, maka akan berpengaruh serta mempunyai kontribusi yang kecil terhadap peningkatan kinerja Islam karyawan muslim tenaga kependidikan Fakultas Ekonomi dan Bisnis Universitas.

Kelima, diantara 6 faktor kepuasan kerja yang terdiri dari pekerjaan itu sendiri, 
gaji atau upah, peluang promosi, kondisi kerja, rekan sekerja dan pengawasan, yang mempunyai pengaruh dominan yaitu rekan sekerja. Beberapa alasan bahwa rekan sekerja mempunyai faktor yang dominan karena karyawan merasa bahwa gaji bukan lagi menjadi faktor utama dalam menentukan kepuasan yang ingin mereka capai, melainkan rekan kerja yang kooperatif dalam melakukan pekerjaan yang dihadapi. Selain itu, karyawan sudah merasa puas dengan statusnya sebagai pegawai tetap di tempat mereka bekerja.

\section{DAFTAR PUSTAKA}

Algifari. 1997. Analisis Statistik Untuk Bisnis dengan Regresi, Korelasi, dan Nonparametrik. Edisi Pertama. Yogyakarta: BPFE-YOGYAKARTA. 2000. Analisis Regresi Teori, Kasus, dan Solusi. Edisi Kedua. Yogyakarta: BPFE-YOGYAKARTA.

Al-Qur'an dan terjemahannya. 2005. Tim Disbintalad. Jakarta: Sari Agung Anogoro, Panji dan Ninik Widiyanti. 1990. PSIKOLOGI DALAM PERUSAHAAN. Cetakan pertama. Jakarta : RINEKA CIPTA

Anoraga, Panji. 2006. Psikologi Kerja. Cetakan keempat. Jakarta: Rineka Cipta

Anshori, Muslich \& Sri Iswati. 2009. Metode Penelitian Kuantitatif. Cetakan pertama. Surabaya: Airlangga University Press.

Arikunto, Suharsimi. 2010. Prosedur Penelitian Suatu Pendekatan Praktik. Jakarta: Rineka Cipta.

As'ad, Moch. 1998. Seri Ilmu Sumber Daya Manusia: Psikologi Industri. Liberty : Yogyakarta.
Azwar, Saiffudin. 1997. Sikap Manusia Teori dan Pengukurannya. Yogyakarta: Pustaka Pelajar.

A. Mas'adi, Ghufron. 2002. Fiqh Muamalah Kontekstual. Jakarta: Raja Grafindo.

Chablullah, Wibisono. Pengaruh Motivasi Spiritual terhadap Kinerja Karyawan. 2002.

Ghani, M. Abdul. 2005.The Spirituality in Business. cetakan pertama. Jakarta: Pena Pundi Aksara.

Ghazali, Imam. 2005. Aplikasi Multivariate dengan Program SPSS. Edisi ketiga. Semarang: Undip.

Gibson, Ivancevich \& Donnelly. 1996. Organization: Behaviour, Structure, Process. Alih Bahasan Djarkasih. Edisi Kelima. Jakarta: Erlangga.

Hamid Mursi, Abdul. 1997. SDM Yang Produktif pendekatan Al-Qur'an dan sains. Jakarta: Gema Insani Press.

Handoko, T. Hani. 1991. Manajemen. Yogyakarta: BPFE-UGM.

Hasibun, Malayu SP. 1994. Manajemen Sumber Daya Manusia Dasar dan Kunci Keberhasilan. Cetakan keenam. Jakarta: Haji Masagung. Indriantoro, Nur dan Bambang Supomo. 1999. Metodologi Penelitian Bisnis untuk Akuntansi dan Manajemen. Edisi Pertama. Yogyakarta: BPFE.

Ismail Yusanto, Muhammad dan Muhammad Karebet Widjajakusuma. 2002. Menggagas Bisnis Islami. Jakarta: Gema Insani. 
Johan, Rita. Kepuasan Kerja Karyawan Dalam Lingkungan Institusi Pendidikan. 2002.

LPPM. 1994. Manajemen Perilaku dalam Organisasi. Jakarta: LPPM.

Luthans, F. 2005. Organizational Behavior. Mc Graw-Hill Book CoSingapore, Singapura.

Qurrotul'aini, Aan. Pengaruh Kepuasan Kerja dan Disiplin Kerja Terhadap Kinerja Karyawan Muslim (Studi Kasus di Dedy Jaya Plaza Ketanggungan Brebes). 2011

Rusyd, Ibnu. 2002.Bidayatul Mujtahid terjemahan. Cetakan kedua. Jakarta: Pustaka Amani.

Solimun. 2002. Structural Equation Modeling Lisrel dan Amos. Malang: Penerbit Universitas Negeri Malang.

Sugiyono. 2011. Metode Penelitian Kuantitatif, Kualitatif dan R\&D. Edisi keduabelas. Bandung: Alfabeta.

Sunyoto, Danang. 2010. Uji KHI Kuadrat dan Regresi untuk Penelitian. Edisi Pertama. Yogyakarta: Graha llmu.

Swasto, Bambang. 1996. Pengembangan Sumber Daya Manusia Pengaruhnya Terhadap Kinerja dan Imbalan. Cetakan Pertama. Malang: Universitas Brawijaya.

Taniredja, Tukiran dan Hidayati Mustafidah. 2011. Penelitian Kuantitatif: Sebuah Pengantar. Bandung: Alfabeta.

Tasmara, Toto. 1995. Etos Kerja Pribadi Muslim. Yogyakarta: PT. Dana Bhakti Wakaf.
Usman, Husaini. 2010. Manajemen : teori,praktik dan riset pendidikan. edisi ketiga. Jakarta: bumi aksara. Wexley, Kenneth N., \& Gary A. Yukl. 1988. Perilaku Organisasi dan Psikologi Personalia. Jakarta: Binarupa Aksara.

Wijono, Sutarto. 2010. Psikologi Industri \& Organisasi. Cetakan pertama. Jakarta: Kencana Prenada Media Group. 